\title{
CRIMINAL LAW CONSIDERATIONS (Ratio Decidendi)
}

\author{
Prayitno Iman Santosa \\ Universitas Muhammadiyah Tangerang, \\ Magister Hukum \\ Jalan Perintis Kemerdekaan I Babakan No.33, RT.007/RW.003, Cikokol, Kec. Tangerang, Kota Tangerang, Banten \\ 15118 \\ Correspondence email: adameva149@gmail.com
}

\begin{abstract}
Judicial practice in Indonesia, judging from the decisions of criminal cases, generally judges give legal considerations only to prove the elements of a criminal offense. In contrast, the determination of the crime is not objectively considered, and most are merely considerations of incriminating and mitigating matters. On the other hand, the judge has absolute authority in imposing a crime; the judge's freedom is guaranteed by law. The supreme power of judges who are used freely without objective measures has the potential to produce corrupt decisions and injustices. Criminal objectives must be aligned with legal goals, namely to realize penalties that guarantee legal certainty, justice, and expediency. Ideally, good sentences reflect the three purposes of the law.
\end{abstract}

KEYWORDS: Criminalization, certainty, fairness, expediency

\section{INTRODUCTION}

The freedom of judges in Indonesia is based on the independence of judicial power guaranteed by Article 24 of the 1945 Constitution, which is further elaborated in Act Number 14 of 1970 concerning the Principles of Judicial Power, as amended by Law Number 4 of 2004, and finally with Law Number 48 the Year 2009. (Borman, 2017; Butt, 2012; Dewi et al., 2016) Freedom and independence or independence of judges in deciding cases are intended as a power that is free from the influence of other powers such as the executive and legislative, free from coercion, free from recommendations coming from outside or from the internal Judiciary, except in cases where what is permitted by law. (Daming, 2016; Hertoni, 2015; Luhukay, 2019) The independence of the judiciary bodies and the Judiciary Power is essential as one of the conditions of the rule of law. It has been universally accepted and emphasized in various international legal instruments, (Elias, 2014; Handoko, 2015; Surono, 2013; Usman, 2015) namely among others in Article 10 Universal Declaration of Human Rights; Article 14 International Covenant on Civil and Political Rights; Vienna Declaration and Program for Action 1993 paragraph 27; International Bar Association Code 1982 Minimum Standards for Judicial Independence in New Delhi; Universal Declaration of Independence in 1983 in 
Montreal, Canada; Statement of Beijing Principles on the Independence of Justice in the Asian Jurisdiction in 1995. (Bobek \& Kosař, 2014; Kennedy, 1995; Piana, 2010)

Judicial powers are free but limited because ultimately, these powers must be subject to the rule of law itself. (Luhukay, 2019; Priyadi, 2013) Regarding the freedom of judges, Paulus E Lotulung said: "Judges are" subordinated "to the law and cannot act "contra legem". (Lotulung, 2003) The independence of judges must be balanced with their partners, namely judicial accountability, limited by legal accountability, defined by the following signs: accountability; moral and ethical integrity; transparency; oversight (control); professionalism and impartiality; independence of judicial power also means protection for judges as law enforcers to be free from influences and directives that may originate among others: Institutions outside the judiciary bodies, both executive and legislative bodies, etc. Private institutions within the Judiciary itself, Influences of litigants, Influences of community pressures, both national and international, and The "trial by the press" influences.. (Borman, 2017; Djafar, 2016; Suhariyanto, 2012; Wajdi, 2017)

The freedom of judges is a reflection of the freedom of judicial power guaranteed by the constitution and is universal, but that freedom is limited by the rules of law itself and accountability. (Fahmiron, 2016; Wantu, 2009; Widodo, 2011) This restriction is intended so that the freedom of judges does not exceed the limits of fairness which can lead to arbitrariness, which can harm others. If judicial power is given unlimited freedom, then the worry of the judge will use his authority for the interests that are not under justice is very likely to occur, because this judicial power is prone to be misused.(Destria \& Monica, 2019; Tumpa, 2015)

Judges in the trial process are faced with choices depending on the perspective of the judge in understanding and giving meaning to legal concepts, which may differ from one judge to another, perhaps in practical terms, perhaps in terms of systematics, perhaps in terms of achievement his sense of justice, and from the foothold of the legal theory used. (Nasrulloh, 2015; Selviria, 2019)Judges in defining law are very dependent on their theoretical or philosophical position, it can be positivistic, empirical, and critical or other teachings, because judges are free to make choices, even though the laws and regulations, even the legal norms faced are the same, to produce a perspective and definition of the law in a manner different too.(Nugroho, 2015; Tutik, 2014)

Gustav Radbruch, regarding the idea or basic value of law based on the basic idea of law, namely justice or justice, expediency, and certainty.(Haldemann, 2005; Radbruch, 2003) Ideally, judges can realize the basic idea of law in their decisions, namely realizing justice, usefulness and legal certainty, but there are difficulties when declaring justice with legal certainty, because if the value of justice is emphasized it will reduce the value of legal certainty and vice versa if legal certainty is emphasized it will reduce the sense justice, which ultimately judges who emphasize the basic value of justice can be different from judges who emphasize certainty. (Mappiasse, 2017; Syamsudin \& SH, 2011; Widodo, 2011) 
The basic idea of the law is realized through the process of trying the defendant includes: the process of obtaining legal facts at the trial, analyzing the facts by confirming, qualifying, and constructing the facts. Constituting means evaluating whether the proposed event is a legal case.(Gultom \& Sularto, 2016; Johny, 2009; Khalid, 2014) The event that he had constituted as an event that had actually happened was then classified. To qualify means to assess the event that actually happened, including what legal relationship or which, in other words, find the law for the event that has been confirmed by applying the rule of law to the event. Finally, after confirming and qualifying the event, the judge must construct or give his constitution, this means that the judge sets the law for the person concerned, namely giving justice. Here the Judge draws a conclusion from the existence of a major premise, namely (legal) regulation, and minor premises, namely the event (legal facts). (Astutiningrum, 2016; Fahriza, 2015; Mustofa, 2016; Setyowati, 2014)

The constituent process does not merely conclude from the major premise to the minor premise, but must give sufficient consideration regarding the conviction. In general, judges in determining the severity of a crime that will be imposed on the defendant only bases their feelings, accompanied by the inclusion of damaging matters and mitigating matters which are still conventional and monotonous, merely fulfilling the formality of the decision. It is not uncommon for judges to just search safely by basing the demands of the Public Prosecutor if ordinary criminal cases are decided half of the demands of the Public Prosecutor do not appeal if special criminal acts are decided 3/4 (three-fourths) of the prosecutor's claim is not appeal. The reflection of justice is not seen in the ratio of judicial decisions like that. Absolute judges' freedom is often used to protect against bad (corrupt) decisions.

Based on the description above, then the problem to be investigated is whether the judge has made good legal considerations (ratio decidendi) in determining the criminal sentence imposed on the defendant.

\section{METHODOLOGY}

This type of research is research library research whose data sources are obtained through research on legislation, and a variety of literature and court decisions that have a permanent legal force that is relevant to the object of research. This type of research is analytical descriptive, meaning that the research is carried out by describing, and analyzing data relating to the decisions of criminal judges.

\section{RESULTS AND DISCUSSION}

Criminal rules contained in the articles of legislation charged to the Defendant are still general-abstract, in the sense that when a case occurs and presented to the court, the judge is obliged to give the spirit of justice to justice seekers (justifiable) in the case was concrete through its verdict. This type of 
research is research library research whose data sources are obtained through research on legislation, and a variety of literature and court decisions that have a permanent legal force that is relevant to the object of study. This type of research is analytical descriptive, meaning that the analysis is carried out by describing and analyzing data relating to the decisions of criminal judges.

Criminal rules are not perfectly regulated in law, only controlled abstract as mentioned in Article 5 paragraph (1) of Law No. 48 of 2009, Judges must explore, follow, and understand the legal values and a sense of justice that lives in the community. Judges in deciding criminal proceedings, in general, have not considered in detail in the conviction, as reflected in the judges' decisions that merely include consideration of incriminating matters and which alleviate the classic and monotonous ones.

Judges are given absolute power, so they are free to determine their sentences throughout the range of crimes that are threatened in criminal articles that have been proven violated. The judge's freedom must be balanced with the judge's obligation to provide objective, accountable, and measurable legal considerations in criminal proceedings.

According to the Moderne Relative of Rechtheorie, the purpose of punishment is to guarantee legal order and to guarantee statutory order regulations are made that contain prohibitions and imperatives (vorboden and geboden) in the form of rules or norms. Violations of the standard are threatened with sanctions. /punishment is torture, just to achieve legal order.

According to vereniginggs theorie (combined theory), the basis for punishment lies in the crime itself, which is retaliation or torture (to criminals), while also paying attention to the purpose of punishment. Punishment in vengeance or torture must be balanced with the wrongdoing of the criminal, pain as compensation for the deed.

Gustav Radbruch's view, regarding ideas or fundamental values of law, rests based on legal concepts, namely justice, expediency, and certainty. Justice and confidence give birth to different demands, expressed in "The Legal Philosophy of Lask, Radbruch, and Dabin" that:

"Justice is equality; eguality of the law demands generality of the legal rule. Justice generalizes to some degree. But equality is not given in reality; always, equality is but an abstraction from actual inequality, taken from a certain point of view. Still from the point of view of expediency, every inequality remains essential; expediency is bound to individualize as far as possible. So justice and expediency become contradictory. The contradiction is illustrated, for instance, by the conflict between administration and administrative courts, the struggle between the tendencies of justice and expediency in criminal law, and, in another field, the contradiction berween 
pedagogic and disciplinary requirements an all mass adecation. This relation of tension, however, is irremovable."

Furthermore, it is said that between certainty and justice, tension can also occur, as well as between truth and expediency. It was stated by Radbruch, translated by Kurt Wilk that:

"But a contradiction arise also between justice and expediency, on the one hand, and legal certainty, on the other. Legal certainty demands positivity, yet positive law claims to be valid without regard to its justice or expediency. Positivity is a fact, positive law presupposes a power that lays it down. So law and fact, law and power, while opposites, enter into a close relation all the same. But legal certainty not only require the validity of legal rules laid down by power and factually carried through; it also makes demands on their contents: it demands that the lawbe capableof being administered with certainty, that it be practicable. It frequently impresses the law with features that conflict with individualizing expediency. For instance, it draws sharp lines where life knows only flowing transitions, or it defines a state of facts by external symptoms instead of the really intended inner facts."

According to the author, the purpose of punishment or punishment must be in line with the objectives of the law, namely: first to maintain public order by realizing legal certainty (legal justice), secondly to fulfill a sense of justice by providing a punishment commensurate with the fault of the accused (moral justice), and third, punishment to provide benefits for the defendant and the victim and the community (social justice).

Criminalization must realize legal certainty because the State of Indonesia is a State based on law, not based on power, the statement stated in the provisions of Article 1 paragraph (3) of the 1945 Constitution. As a consequence, the actions or actions of the authorities/government and institutions others, including members of the community, must comply and be based on the law. Legal certainty is needed to guarantee order and order in the community, because legal certainty (general rules/regulations) has the following characteristics:

a. There is coercion from outside (sanctions) from the authorities in charge of maintaining and fostering public order with the intermediaries of the tools.

b. The law applies to anyone.

Judges' decisions must also reflect justice. According to the Institute of Justinian, the word justice is formulated as: "Justice is the constant and continuous purpose which is given to everyone his own", justice is talking about someone's rights when faced with what should be given by those who are entitled to it, if the right He did not accept it, so it was considered unfair, or unfair.

According to Plato, justice or justice does not mean that all people receive the same amount, but the truth, according to Plato as something that can provide 
happiness. For Plato, the sentence is a virtue that contains harmony and balance that cannot be known or explained by rational argument. Plato divides virtue into four categories, namely wisdom or wisdom, courage or determination, and discipline, and justice.

Aristoteles, about justice, puts more emphasis on aspects of morality, further stated that: "truth for the community will only be realized when people obey the general rules that apply to it. Justice means lawful, the law must not be violated, and the rule of law must be followed. Second, justice means equality (equal), saying that the basis of the use of benchmarks of fairness is equality of rights for everyone. Each person gets what they are entitled to proportionally (distributive justice).

John Rawls introduces two principles of justice: first, "each person is to have an equal right to the most extensive basic liberty compatible with a similar liberty for others"; and second, "social and economic inequalities are to be arranged so that they are both (a) reasonably expected to be everyone's advanced, and (b) attached to positions and offices open to all." All social values related to freedom and opportunity, income and wealth, and the basics of self-esteem must be distributed equally unless the unequal distribution of some or all of these values provides the same benefits for everyone.

The concept of justice in Indonesia refers to the fifth principle of Pancasila, namely: "Social justice for all Indonesian people." The truth that Indonesia wants to achieve is justice that is equitable for all the people of Indonesia, but not in the sense of equality and taste.

The law is a tool for the community so that the law must benefit the city, and even the punishment must benefit the community. Utility theory assumes that, in principle, the purpose of the law is only to create benefit or happiness in society. Jeremias Bentham, John Stuart Mill, and David Hume teach that community happiness is a principle for measuring legal justice.

Certainty, justice, and benefit from one another are pressing, like a pendulum clock, if the element of legal certainty is put forward, then the aspect of community justice will be harmed, if prioritizing justice, will reduce the side of legal certainty and usefulness, but if highlighting the benefits will reduce the sense of justice.

The three legal objectives in punishment do not have to be interpreted as one side to the other based on the assessment of priorities as taught in standard priority theory. Still, in the ratio decidendi, it must be reflected that the three legal objectives are accommodated in the decision even though it does not have to be balanced, because naturally the three statutory purposes these will push each other so that sufficient portions of the three legitimate objectives exist even though each part differs according to the priority of the case it faces, as taught in the theory of triangular concept, and casuistic priority theory. 
According to the author, the objective measure of punishment must be based on the legal objectives themselves, namely legal certainty, moral justice, and expediency. Legal certainty (legal justice) as a Range I of Criminal Justice, justice (moral justice) as a Range II of Criminalization and benefits (social justice) as a Range III of Criminalization. These three Penalties Ranges are used as the "Criminal Objective Standards" (SOP), described as follows.

1. Legal justice / Range I Criminal law

Judges are obliged to apply applicable criminal law regulations. Therefore legal certainty is guaranteed, in terms of punishment Judges are given the freedom to sentence according to the relevant criminal law regulations that have been threatened by anyone who commits a criminal offense, meaning the Judge can impose a sentence between the threat of punishment at least up to the maximum penalty of the article or articles which were proven to have been violated by the Defendant.

2. Moral justice / Range II Criminal Justice

The severity of the criminal sentence imposed by the judge must be commensurate with the level of the Defendant's error, along with the impact of the crime and other matters surrounding it, in relation to this matter, to measure the level of error the Defendant objectively uses measures including the motives and the purpose of committing the crime, the inner attitude Criminal offenders, criminal actions carried out by planning, how to commit a crime, the public's view of the crime committed.

The Defendant's error rate is divided into 4 (four) levels, namely:

a. Level I Errors: Implications with mild error rates.

b. Level II Errors: Descriptions with moderate errors.

c. Level III Errors: Implications with severe error rates.

d. Level IV Errors: Complaints with very high error rates.

e. The level of error is related to punishment so that the minimum criminal threat up to the most significant risk is divided into 4 (four) clusters as follows:

1) Cluster I: Level I Error, the Defendant can be convicted of a minimum crime of up to $1 / 4$ (a quarter) of the most significant criminal threat.

2) Cluster II: Level II Mistakes, Defendants can be convicted between $1 / 4$ (a quarter) of the maximum criminal risk up to $1 / 2$ (half) of the greatest criminal risk.

3) Cluster III: Level III Mistakes, Defendants can be convicted between $1 / 2$ (half) of the maximum criminal risk up to $3 / 4$ (three-fourths) of the greatest criminal risk.

4) Cluster IV: Level IV Errors, Defendants can be convicted between $3 / 4$ (three-fourths) of the maximum criminal risk up to the greatest criminal risk.

3. Benefit (Social justice) 
The criminal sentence must provide benefits to the accused, the community, and the victim, as follows:

a. Against the perpetrators: to eliminate the Defendant's ability to commit crimes again, besides that the Defendant in prison can improve.

b. Against the victim: pay attention to the Defendant in restoring the victim due to his behavior.

c. Against the community: recovery of community trauma resulting from the crime so that people's lives can be recovered in a state of harmony and peace.

The benefit relationship with punishment tends to relieve the Defendant. The higher the efforts of the Defendant to restore due to his crime, the higher the leniency given, and vice versa, besides that, it will also pay attention to the psychological community and sociological conditions and interests of the Defendant. follows:

Recovery of due to criminal acts is grouped into 3 (three) levels, as

1) Level I: complete recovery, if the Defendant has returned all of the victim's losses so that the social life code returns to normal.

2) Level II: incomplete recovery, that is, the Defendant has made a recovery effort on the impact of the criminal act, but the victim's loss has not been fully recovered.

3) Level III: there is no recovery; that is, the Defendant did not recover from the victim's injury.

The recovery rate is related to criminal punishment, divided into 3 (three) clusters as follows:

a) Cluster I: The Defendant can be convicted of a minimum criminal threat up to $1 / 3$ (one third) of the highest criminal risk.

b) Cluster II: The Defendant can be convicted between 1/3 (one third) criminal threat up to $2 / 3$ (two thirds) maximum criminal threat.

c) Cluster III: Defendants can be sentenced between 2/3 (two thirds) of the maximum criminal risk up to the greatest criminal risk.

The method of determining the severity of the penalties outlined above is based on three ranges of criminal objectives, namely legal certainty, moral justice, and social justice, called "Three Range of Penalties" (TRP) or "Triple Range Punishment." The theory is used as an objective standard to determine the penalties, which should be applied as a dependency ratio in sentences. The TRP is still general, in applying sanctions it must always be seen on a case-by-case or case basis, based on the classification of criminal 
acts, in this case, the author classifies all criminal acts in 3 (three) categories, as follows:

\section{Extra Ordinary Crime}

Extraordinary crimes are all criminal acts that have a hazardous impact on the wider community, nation, and state, because they are systemic and widespread, including illegal acts of corruption, narcotics, terrorism, and others. The imposition of a criminal offense against extraordinary crime or besides taking into account the minimum and maximum limits of criminal threats (legal justice), is prioritized for moral judgment, so that "moral justice" is considered more dominant in determining criminal punishment, while social justice as a supplement that serves to alleviate criminal defendants within the limits of Range II conviction.

The process of criminalization against extraordinary crimes, according to the SOP, is passed through 3 (three) stages, consecutively reinforced with Range I (legal justice), Range II Criminal (moral jusrice) and Range III Criminal (social justice), as follows:

a. First of all, consideration of Range I of Penalties, namely judges limit the minimum penalty of punishment up to the limit of the maximum penalty, based on criminal rules being violated, the judge may not sentence under the minimum penalty or impose the penalty above the maximum penalty,

b. Second, after knowing the limits of the Range I of punishment, the judge then considers Range II of the Criminal Code, in this case the main measure is the degree of error of the accused / perpetrator, the more preliminary crimes that accompany to arrive at the main purpose of the crime, the higher the evil character of the perpetrator and the more severe the error is assessed, on the other hand the impact of the crime and the other things that surround the crime are considered, the level of error related to criminality is divided into 4 clusters, as follows:

1) If, based on the facts, the trial results prove "minor defendant's mistake", then the Range of criminal convictions against the defendant is in Cluster I of Range II of Criminal Justice.

2) If, based on the facts of the results of the trial, it is proven that "the defendant's error is moderate," then the Range of criminal convictions against the defendant is in Cluster II Range II of Criminal Justice.

3) If, based on the facts of the results of the trial, it is proven that "the defendant's guilt is serious," then the Range of criminal convictions against the defendant is in Cluster III Range II of Criminal Justice. 
4) If, based on the facts, the trial results prove "the defendant's mistake is very severe," then the Range of criminal convictions against the defendant is in Cluster IV Range II of Criminal Justice.

c. The third stage, considered Range III Penalty, for extraordinary crimes as a supplement to the relief of the sentence for the defendant, his position is in the Range II Criminal cluster. Range III The most important punishment is to consider restoration by the defendant after the crime. Recovery of circumstances associated with punishment is divided into 3 (three) Clusters, as follows:

1) If, based on the facts, the trial results prove "there is no restoration," then the range of criminal convictions against the defendant is in Cluster III Range III in the Criminal Range II.

2) If, based on the facts, the trial results prove "there is a partial restoration," then the range of criminal convictions against the defendant is in Cluster II Range III in the Criminal Range II. 3.1. If, based on the facts, the trial results prove "full restoration," then the range of criminal convictions against the defendant is in Cluster I Range III in the Criminal Range II.

3) After determining the Range III Criminal Cluster, then it is determined (in the deliberation of the judge) the severity of the crime in the range of criminal offenses according to Cluster Range III in the Criminal Range II Cluster.

\section{Ordinary Crime}

Ordinary criminal acts are all criminal acts that cause harm only to individuals or small groups of community members, and the impact is not widespread. Criminal imprisonment against ordinary criminal acts aside from taking into account the minimum and maximum limits of criminal threats (legal justice / Range I Penalties), subsequently considered moral justice (Range II Criminalism), and social justice (Range III Criminalism) are taken into account in a balanced way. The process of the ratio of punishment to the ordinary crime successively considered Range I Criminal (legal justice), Range II Criminal (moral justice) and Range III Criminal (social justice), as follows:

a. First of all, consideration of Range I of Penalties is the limit of the minimum penalty to the maximum penalty, based on criminal rules being violated, the judge may not sentence under the minimum penalty or impose the penalty above the maximum penalty.

b. Second, after knowing the limits of the Range I of punishment, the judge then considers Range II of the Criminal Code, in this case the main measure is the degree of error of the accused/perpetrator, the more 
preliminary crimes that accompany to arrive at the main purpose of the crime, the higher the evil character of the perpetrator and the more severe the error is assessed, on the other hand the impact of the crime and the other things that surround the crime are considered, the level of error related to criminality is divided into 4 clusters, as follows:

1) If, based on the facts, the trial results prove "minor defendant's mistake," then the range of criminal convictions against the defendant is in Cluster I of Range II of Criminal Justice.

2) If, based on the facts of the results of the trial, it is proven that "the defendant's error is moderate," then the range of criminal convictions against the defendant is in Cluster II Range II of Criminal Justice.

3) If, based on the facts of the results of the trial, it is proven that "the defendant's guilt is serious," then the range of criminal convictions against the defendant is in Cluster III Range II of Criminal Justice.

4) If, based on the facts, the trial results prove "the defendant's mistake is very severe," then the range of criminal convictions against the defendant is in Cluster IV Range II of Criminal Justice.

After determining the Range II Criminal Cluster, it is then determined (in the deliberation of the judge) the severity of the crime in the range of sins, according to the Cluster in the Criminal Range II.

c. The third stage considered Range III Penalties. Against ordinary crimes, Range III Criminal status is equal and equal to Range II Criminal. Thus the position of Range III Criminal in everyday criminal acts is different from the area of Range III Criminal in extraordinary crimes. Range III The most important punishment is to consider restoration by the defendant after the crime. Recovery of circumstances associated with discipline is divided into 3 (three) Clusters, as follows:

1) If, based on the facts, the trial results prove "there is no restoration," then the range of criminal convictions against the defendant is in Cluster III Range III of Criminal Justice.

2) If, based on the facts, the trial results prove "there is a partial restoration," then the range of criminal convictions against the defendant is in Cluster II Range III of Criminal Justice.

3) If, based on the facts of the results of the trial proven "full restoration," then the range of criminal convictions against the defendant is in Cluster I of Range III of Criminal Justice. 
After determining the level of recovery (restoration), we then decided (through deliberations of the judges) the severity of the crime to the defendant/perpetrator.

Criminal acts against ordinary crimes are calculated by combining the results of crimes based on Range II with Range III Penalties, then divided into 2 (two), the results of which are determinants of the severity of the criminal sentences against defendants who commit ordinary crimes.

\section{Misdemeanor}

Misdemeanor are mistakes that arise due to negligence or not solely due to the perpetrators' evil intentions, but rather occur due to the victims themselves or other parties or even the perpetrators as victims of other criminal acts/crimes.

Criminal imprisonment against criminal offenses with minor errors must pay more attention to the interests of the defendant in the future, balanced with the restoration of victims' losses by the defendant (restorative justice). Therefore the dominant punishment must be considered in terms of "social justice," while in terms of moral justice seconder position.

The process of the ratio of criminal punishment to the ordinary crime successively considered Range I Criminal (legal justice), Range III Criminal (social justice) only then Range II Criminal (moral judgment). So it is different from the order of ratio decidendi in extraordinary crimes or ordinary crime, from now on described as follows:

a. The first step considered Range I of Penalty is the limit of the minimum sentence to the maximum sentence, based on the criminal rules being violated. The judge may not sentence under the minimum penalty or impose the sentence above the maximum penalty.

b. The second step considered Range III Penalties. Against criminal offenses with minor errors, Range III Criminal status is more dominant in determining the severity of the crime to be imposed. In contrast, Range II Criminal status is seconder, meaning that the level of recovery (recovery) of the impact of sin by the defendant as forgiveness for the crime committed. Because in principle, the defendant has no malicious intent, so the focus of legal considerations is to pay more attention to the future of the defendant's life. Therefore the Range II of the Criminal Act is not the primary determinant in the conviction of a criminal offense with a minor error. Range III The most important punishment is to consider restoration by the defendant after the crime. Restoration (restoration) associated with discipline divided into 3 (three) Clusters, as follows: 
1) If, based on the facts, the trial results prove "there is no restoration," then the range of criminal convictions against the defendant is in Cluster III Range III of Criminal Justice.

2) If, based on the facts, the trial results prove "there is a partial restoration," then the range of criminal convictions against the defendant is in Cluster II Range III of Criminal Justice.

3) If, based on the facts of the results of the trial proven "full restoration," then the range of criminal convictions against the defendant is in Cluster I of Range III of Criminal Justice.

c. The third step, after knowing the limits of Range III conviction, the judge then considers Range II Criminal, in this case the main measure is the level of error of the defendant / perpetrator, the more preliminary crimes that accompany to arrive at the main goal of the crime, the higher the evil character of the perpetrator and it is judged that the error is more severe, on the other hand the impact of crime and other matters that are surrounding the criminal offense, the level of error related to punishment is divided into 4 clusters, as follows:

1) If, based on the facts, the trial results prove "minor defendant's mistake," then the range of criminal convictions against the defendant is in Cluster I Range II in the Criminal Range III.

2) If, based on the facts of the results of the trial, it is proven that "the defendant's error is moderate," then the range of criminal convictions against the defendant is in Cluster II Range II in Range III Penalty.

3) If, based on the facts of the results of the trial, it is proven that "the defendant's guilt is serious," then the range of criminal convictions against the defendant is in Cluster III Range II in the Criminal Range III.

4) If, based on the facts, the trial results prove "the defendant's mistake is very severe," then the range of criminal convictions against the defendant is in Cluster IV Range II in Range III Penalty.

After determining the Range III Criminal Cluster, it is then determined (in the deliberation of judges) the severity of the crime in the range of criminal offenses according to Cluster Range II in the Criminal Range III Cluster.

The application of the "Three Penalties Range" with 3 (three) variants as the ratio decidendi in determining the conviction by the author is called the "Standards of Criminal Objectives" (SOP), intended to be an objective measure guiding judges in assessing the severity of the criminal imposed on the Defendant, so that transparent, accountable. Measurable criminal decisions are created, ultimately minimizing corrupt and unjust illegal choices. 
In general, judges have not provided specific legal considerations in determining the criminal sentences on the Defendant. Judges' decisions related to this matter only consider incriminating and mitigating matters, the contents of which are still conventional and monotonous, not sufficiently correlated with the severity of criminal convictions. As a result, many criminal judge decisions are judged to be unfair and unsatisfactory because there are no objective, accountable and transparent considerations that can be understood, especially by Yusticiabelen.

\section{CONCLUSION}

Judges' legal considerations (ratio decidendi) in determining the severity of criminal offenses have not been good, because in general it is only reflected in the consideration of things that are burdensome and mitigating that are conventional and monotonous tend to be merely to fulfill formalities, on the other hand judges hold absolute power, it becomes a prone to corruption and injustice, it should be in determining the severity of the punishment the judge applies the Criminal Objective Standards based on Triple Ranges Punishment, to minimize corrupt criminal decisions, thus giving birth to justice.

\section{BIBLIOGRAPHY}

Astutiningrum, Y. P. (2016). Pertimbangan Majelis Hakim Dalam Peranan Saksi Ahli Dalam Pembuatan Visum Et Repertum Sebagai Alat Bukti Dalam Perkara Penganiayaan Yang Menyebabkan Kematian. Verstek, 4(1).

Bobek, M., \& Kosař, D. (2014). Global Solutions, local damages: A critical study in judicial councils in Central and Eastern Europe. German Law Journal, 15(7), 1257-1292.

Borman, M. S. (2017). INDEPENDENSI KEKUASAAN KEHAKIMAN DARI PENGARUH KEKUASAAN DI INDONESIA. Lex Journal: Kajian Hukum \& Keadilan, 1(1).

Butt, S. (2012). Indonesia's Constitutional Court: Conservative activist or strategic operator? The Judicialization of Politics in Asia, 98-116.

Daming, S. (2016). PELUANG DAN TANTANGAN PERWUJUDAN SISTEM PERADILAN YANG BERSIH DAN BERKUALITAS. YUSTISI, 3(2), 39.

Destria, E. D., \& Monica, D. R. (2019). PROSPEKTIF PENERAPAN RECHTERLIJK PARDON (PEMAAFAN HAKIM) DALAM PUTUSAN PENGADILAN (Studi Konsep RKUHP 2018). POENALE: Jurnal Bagian Hukum Pidana, 7(1).

Dewi, Y. T. N., Tjandra, W. R., \& Niemann, G. R. (2016). Independence of Judicial Power as a Foundation of Human Rights Judicial Function in Indonesia. International Journal of Social Science and Humanity, 6(3), 239. 
Djafar, Z. S. (2016). Politik Hukum Menciptakan Lembaga Peradilan Yang Independen, Wibawa Dan Akuntabel. Lex Privatum, 4(5).

Elias, R. F. (2014). Penemuan hukum dalam proses peradilan pidana di Indonesia. Jurnal LPPM Bidang EkoSosBudKum, 1(1), 1-11.

Fahmiron, F. (2016). INDEPENDENSI DAN AKUNTABILITAS HAKIM DALAM PENEGAKAN HUKUM SEBAGAI WUJUD INDEPENDENSI DAN AKUNTABILITAS KEKUASAAN KEHAKIMAN. LITIGASI, 17(2), 3467-3515.

Fahriza, A. M. (2015). Tinjauan Tentang Pembuktian Dakwaan Penuntut Umum dengan Alat Bukti Keterangan Saksi Verbalisan dan Implikasinya terhadap Putusan dalam Perkara Perlindungan Anak (Studi Kasus Putusan Pengadilan Negeri Bulukumba Nomor: 101/Pid. B/2014/PN. BLK).

Gultom, S. S., \& Sularto, R. B. (2016). Ide Dasar Keseimbangan Dalam Penetapan Status Tersangka Sebagai Objek Praperadilan Oleh Kekuasaan Kehakiman Di Indonesia. Law Reform, 12(1), 101-120.

Haldemann, F. (2005). Gustav Radbruch vs. Hans Kelsen: A debate on Nazi law. Ratio Juris, 18(2), 162-178.

Handoko, D. (2015). Kekuasaan Kehakiman di Indonesia. HAWA DAN AHWA.

Hertoni, M. (2015). Independensi Hakim dalam Mencari Kebenaran Materiil. Lex Crimen, 5(1).

Johny, R. H. (2009). Contempt of Court (Kajian Tentang Ide Dasar dan Implementasinya Dalam Hukum Pidana). Jurnal Dinamika Hukum, 9(2), 169180.

Kennedy, A. M. (1995). Judicial Ethics and the Rule of Law. . Louis ULJ, 40, 1067.

Khalid, A. (2014). Penafsiran Hukum oleh Hakim dalam Sistem Peradilan di Indonesia. Al-Adl: Jurnal Hukum, 6(11).

Lotulung, P. E. (2003). Kebebasan Hakim dalam Sistem Penegakan Hukum. Makalah Disampaikan Pada Seminar Pembangunan Hukum Nasional VIII, Tema "Penegakan Hukum Dalam Era Pembangunan Berkelanjutan", Diselenggarakan Oleh Badan Pembinaan Hukum Nasional Departemen Kehakiman Dan Hak Asasi Manusia RI, Denpasar, 14-18.

Luhukay, R. S. (2019). INDEPENDENSI KEKUASAAN KEHAKIMAN PASCA AMANDEMEN UNDANG-UNDANG DASAR TAHUN 1945 DAN RELEVANSINYA BAGI PENEGAKAN HUKUM YANG BERKEADILAN DI INDONESIA. Jurisprudentie: Jurusan Ilmu Hukum Fakultas Syariah Dan Hukum, 6(1), 135154.

Mappiasse, S. (2017). Logika hukum pertimbangan putusan hakim. Prenada Media. Mustofa, I. (2016). Jendela Logika dalam Berfikir; Deduksi dan Induksi sebagai Dasar Penalaran Ilmiah. El-Banat: Jurnal Pemikiran Dan Pendidikan Islam, 6(2), 1-21. 
Nasrulloh, A. S. (2015). Asas ultra petitum partium dalam penemuan hukum oleh hakim perspektif hukum progresif [PhD Thesis]. Universitas Islam Negeri Maulana Malik Ibrahim.

Nugroho, S. S. (2015). MENUJU PEMIKIRAN FILOSOFIS ILMU HUKUM HOLISTIK (Kajian Kritis terhadap Ilmu Hukum Positivistik Menuju Postposivistik dengan Pendekatan Chaos Theory of Law). Jurnal Yustisia Merdeka, 1(2).

Piana, D. (2010). Judicial accountabilities in new Europe: From rule of law to quality of justice. Gower Publishing, Ltd.

Priyadi, A. (2013). Politik Hukum Kekuasaan Kehakiman (Tinjauan Tentang Kemandirian Kekuasaan Kehakiman Setelah Dikeluarkannya UU No. 48 Tahun 2009). Cakrawala Hukum, 15(41), 23192.

Radbruch, G. (2003). Rechtsphilosophie (Vol. 2043). CF Müller GmbH.

Selviria, S. (2019). Sistem Pemidanaan Indonesia Ditinjau dari Pendekatan American Legal Realism dan Scandinavian Realism. Simbur Cahaya, 25(2), 189-206.

Setyowati, H. (2014). Tinjauan Tentang Pengesampingan Hukum Pembuktian Oleh Hakim Sebagai Alasan Penuntut Umum Mengajukan Kasasi Terhadap Pembebasan Dakwaan Primair Dalam Putusan Perkara Korupsi (Studi Kasus Dalam Putusan Mahkamah Agung No. 1389 K/Pid. Sus/2012).

Suhariyanto, B. (2012). MENUNTUT AKUNTABILITAS PUTUSAN PENGADILAN MELALUI PEMIDANAAN TERHADAP HAKIM. Jurnal Hukum Dan Peradilan, 1(2), 249-274.

Surono, A. (2013). Fiksi hukum dalam pembuatan Peraturan Perundang-undangan. Fakultas Hukum Universitas Al-Azhar Indonesia.

Syamsudin, M., \& SH, M. (2011). Konstruksi Baru Budaya Hukum Hakim Berbasis Hukum Progressif. Kencana.

Tumpa, H. A. (2015). Penerapan Konsep Rechtsvinding dan Rechtsschepping oleh Hakim dalam Memutus Suatu Perkara. Hasanuddin Law Review, 1(2), 126138.

Tutik, T. T. (2014). Ilmu Hukum: Hakekat Keilmuannya Ditinjau dari Sudut Filsafat Ilmu dan Teori Ilmu Hukum. Jurnal Hukum \& Pembangunan, 44(2), 245-268.

Usman, A. H. (2015). Kesadaran Hukum masyarakat dan Pemerintah sebagai Faktor Tegaknya Negara Hukum di Indonesia. Jurnal Wawasan Yuridika, 30(1), 26-53.

Wajdi, F. (2017). Urgensi Etika dalam Peradilan. Etika Dan Budaya Hukum Dalam Peradilan, 117.

Wantu, F. M. (2009). Refleksi Atas Konsep Peradilan Satu Atap Menuju Pada Tujuan Kekuasaan Kehakiman Yang Mandiri. Jurnal Legalitas, 2(3), 12513.

Widodo, J. P. (2011). Penalaran Hukum Dalam Proses Mengadili Perkara Pidana Dalam Kerangka Kebebasan Hakim. Pranata Hukum, 6(2), 26727. 